Research article

Open Access

\title{
A new classification of HLA-DRB1 alleles differentiates predisposing and protective alleles for autoantibody production in rheumatoid arthritis
}

\author{
Pierre-Antoine Gourraud1, Philippe Dieudé2, Jean-Frédéric Boyer ${ }^{3,4}$, Leonor Nogueira5, \\ Anne Cambon-Thomsen7, Bernard Mazières ${ }^{3,4}$, François Cornélis ${ }^{6}$, Guy Serre ${ }^{5}$, Alain Cantagrel ${ }^{3,4}$ \\ and Arnaud Constantin 1,3,4
}

\author{
1Service d'Epidémiologie CHU Toulouse, INSERM, U558, Université Paul Sabatier Toulouse III, Faculté de Médecine, 37 allées Jules Guesde, \\ Toulouse Cedex 7, 31073, France \\ ${ }^{2}$ Service de Rhumatologie, CHU Bichat Claude-Bernard, 46 rue Henri Huchard, Paris, 75018, France \\ ${ }^{3}$ GRCB40, UFR Sciences Médicales Rangueil, 1 avenue du Professeur Jean Poulhès, Toulouse Cedex 9, 31059, France \\ 4Service de Rhumatologie, CHU Toulouse Rangueil, 1 avenue du Professeur Jean Poulhès, Toulouse Cedex 9, 31059, France \\ ${ }^{5}$ Laboratoire de Biologie Cellulaire et Cytologie, CHU Toulouse Purpan, Place du Docteur Baylac, Toulouse cedex 9, 31059, France \\ ${ }^{6}$ GenHotel, Genopole, 2 rue Gaston Crémieux, Evry Cedex, 91057, France \\ 7INSERM, U558, Faculté de Médecine, 37 allées Jules Guesde, Toulouse Cedex 7, 31073, France \\ Corresponding author: Arnaud Constantin, constant@cict.fr
}

Received: 27 Nov 2006 Revisions requested: 2 Feb 2007 Revisions received: 5 Mar 2007 Accepted: 12 Mar 2007 Published: 12 Mar 2007

Arthritis Research \& Therapy 2007, 9:R27 (doi:10.1186/ar2131)

This article is online at: http://arthritis-research.com/content/9/2/R27

(C) 2007 Gourraud et al., licensee BioMed Central Ltd.

This is an open access article distributed under the terms of the Creative Commons Attribution License (http://creativecommons.org/licenses/by/2.0), which permits unrestricted use, distribution, and reproduction in any medium, provided the original work is properly cited.

\begin{abstract}
The HLA-DRB1 gene was reported to be associated with anticitrullinated protein/peptide autoantibody (ACPA) production in rheumatoid arthritis (RA) patients. A new classification of HLA-DRB1 alleles, reshaping the shared epitope (SE) hypothesis, was recently found relevant in terms of RA susceptibility and structural severity.

We investigated the relevance of this new classification of HLADRB1 $\mathrm{SE}^{+}$alleles in terms of rheumatoid factor (RF) and ACPA production in a sample of French RA patients.

We studied 160 early RA patients included in a prospective longitudinal cohort of French Caucasian patients with recentonset arthritis. RF, anticyclic citrullinated peptide 2 (anti-CCP2) and antideiminated human fibrinogen autoantibodies (AhFibA) were assessed in all patients at inclusion. The HLA-DRB1 gene was typed by PCR-sequence specific oligonucleotides probes
\end{abstract}

(PCR-SSOP), and SE+ alleles were classified into four groups (S1, S2, S3P, S3D) according to the new classification.

The new classification of HLA-DRB1 SE+ alleles distinguishes predisposing and protective alleles for RF, anti-CCP2 or AhFibA production. The presence of S2 or S3P alleles is associated with both RF, anti-CCP2 or AhFibA positivity, whereas the presence of S3D or S1 alleles appears to be protective for RF, anti-CCP2 or AhFibA positivity.

The new classification of HLA-DRB1 $\mathrm{SE}^{+}$alleles is relevant in terms of autoantibody production in early RA patients by differentiating predisposing and protective alleles for RF or ACPA production.

\section{Introduction}

Since early rheumatoid arthritis (RA) is often indistinguishable from other inflammatory joint diseases, recent-onset inflammatory synovitis poses a diagnostic and prognostic challenge to rheumatologists [1]. The identification and validation of immunologic and genetic markers with strong diagnostic and prognostic value in early RA may help rheumatologists to meet this challenge [2].

$\overline{\mathrm{ACPA}}=$ anticitrullinated protein/peptide autoantibody; AhFibA = antideiminated human fibrinogen autoantibodies; anti-CCP = anticyclic citrullinated peptide; ELISA = enzyme-linked immunosorbent assay; HLA = human leukocyte antigen; MHC = minor histocompatibility complex, PCR = polymerase chain reaction; $\mathrm{RA}=$ rheumatoid arthritis; $\mathrm{RF}=$ rheumatoid factor; $\mathrm{SE}=$ shared epitope. 
Among immunologic markers, anticitrullinated protein/peptide antibodies (ACPAs) constitute relevant tools in the diagnosis and prognosis of early RA. Citrulline is a nonstandard amino acid, generated by post-translational modifications of several proteins by deimination of arginine residues by peptidylarginine deiminases $[3,4]$. The citrulline moiety is the true determinant in proteins recognized by antiperinuclear factor [5], antikeratin antibodies [6], antifilaggrin antibodies [7], anticyclic citrullinated peptide (anti-CCP) antibodies [8] and antideiminated human fibrinogen autoantibodies (AhFibA) [9-11]. ACPAs may be detected in healthy individuals, years before the onset of symptoms of RA [12,13], and may predict progression to persistent erosive arthritis or to RA in patients with undifferentiated arthritis [14-16]. ACPAs are as sensitive as, and more specific than, rheumatoid factor (RF) for early RA diagnosis [17-19]. Furthermore, ACPAs represent a prognostic factor for erosive disease in early RA [20-24].

Among genetic markers, the HLA-DRB1 gene has been clearly involved in the pathogenesis of RA $[25,26]$. The association between HLA-Dw4 and RA was first reported in 1976 [27]. The development of HLA-DRB1 genotyping led to the demonstration that different HLA-DR4 alleles were not equally associated with RA and that several non-DR4 HLA-DRB1 alleles were also associated with the disease. The shared epitope (SE) hypothesis, first proposed in 1987, represents an approach to understand the molecular genetics of susceptibility to RA. The SE hypothesis assumes that HLA-DRB1 alleles encoding a highly conserved amino acid sequence, known as the SE - which is characterized by the RAA pattern at positions 72-74 of the third hypervariable region of different HLA$\mathrm{DR} \beta_{1}$ chains - are associated with susceptibility to RA [28]. HLA-DRB1 alleles encoding the SE were then associated with structural severity of RA [29] and have been more recently associated with production of ACPAs [9,12,24,30-32].

As was done in previous attempts [33,34], du Montcel and colleagues recently introduced a new classification of HLADRB1 alleles that reconsiders the SE hypothesis [35]. In terms of susceptibility to RA, this new classification suggests that the risk of developing RA depends on whether the RAA sequence occupies positions 72-74 but the risk is modulated by the amino acids at position 71 ( $\mathrm{K}$ confers the higher risk, $\mathrm{R}$ an intermediate risk, $A$ and $E$ a lower risk) and at position 70 ( $Q$ or $R$ confers a higher risk than D) [35-37] complexifying the classical SE epitope classification based on the presence of RAA in positions 72-74. In terms of structural severity of RA, this new classification allowed the differentiation of predisposing or protective alleles (two effects) - respectively characterized by the DRRAA or by the DERAA amino acid pattern at positions 70-74 [36] - which was not possible using the classical SE epitope classification based on the only presence of RAA in positions $72-74$.
In the present study, we investigated the relevance of this new classification of HLA-DRB1 alleles in terms of RF and ACPA production in a cohort of French Caucasian patients with early RA. Interestingly, the new classification of HLA-DRB1 alleles allows the differentiation between predisposing and protective alleles for autoantibody production.

\section{Materials and methods \\ Patients}

One hundred and sixty Caucasian outpatients were selected from the Rangueil Midi-Pyrénées cohort, which involved patients with early arthritis who attended the Rangueil Hospital Department of Rheumatology between November 1992 and December 1997, according to the following criteria: the American College of Rheumatology 1987 criteria for RA [38], disease duration $<1$ year from the first clinical manifestation of $\mathrm{RA}$, and age over 16 years.

Each individual included in the Rangueil Midi-Pyrénées cohort signed an informed consent form. The protocol was initially approved by the Committee for the Protection of Persons Participating in Biomedical Research (French law 88-1138 December 20, 1988).

\section{Detection of RF and ACPAs}

Blood samples were collected at baseline, immediately centrifuged and stored at $-80^{\circ} \mathrm{C}$ until assayed. RF was quantified by nephelometry according to the manufacturer's recommendations (RF Reagent, IMMAGE immunochemistry system; Beckman Coulter, Inc., Fullerton, CA, USA). Anti-CCP2 antibodies were detected by ELISA according to the instructions of the manufacturer (IMMUNOSCAN RA; Euro-Diagnostica, Arnhem, The Netherlands). AhFibA were detected with a recently developed inhouse ELISA, using in vitro deiminated human fibrinogen as immunosorbent $[9,10]$. The cut-off points of the two ELISAs were previously set so they reached the same diagnostic specificity of $98.5 \%$.

\section{HLA-DRB1 genotyping and allele classification}

Genomic DNA was extracted from ethylenediamine tetraacetic acid anticoagulated peripheral blood, using a standard proteinase $\mathrm{K}$ digestion and phenol/chloroform extraction method, in all patients at the time of inclusion. HLA-DRB1 typing and subtyping were performed by a PCR-based method, using a panel of sequence-specific oligonucleotide probes [36].

HLA-DRB1 alleles were pooled according to the new classification proposed by du Montcel and colleagues $[35,36]$. Briefly, the HLA-DRB1 alleles were first divided into two groups according to the presence or absence of the RAA sequence at positions $72-74$ and were denoted $S$ and $X$ alleles, respectively. The $S$ alleles were subsequently divided into four groups according to the amino acid at position 71: an alanine $(A)$, a glutamic acid $(E)$, a lysine $(K)$, or an arginine $(R)$. Different groups were thus defined in the new classification: 
S1 for ARAA and ERAA, S2 for KRAA, S3 for RRAA, and X for all non-RAA patterns. Since an aspartic acid (D) at position 70 was reported to be protective against RA susceptibility in comparison with a glutamine $(\mathrm{Q})$ or an arginine $(\mathrm{R})$ at the same position [39], two additional groups were defined: S3D for DRRAA, and S3P for QRRAA or RRRAA $[35,36]$ (Table 1).

\section{Statistical analysis}

Agreements with Hardy-Weinberg equilibrium were tested using Pearson's chi-square test and Fischer's exact test when relevant. The association between the HLA-DRB1 gene polymorphism and RF or ACPAs was tested by comparing (by the chi-square test or the exact Fisher test when relevant) the distribution of positive or negative patients for RF or anti-CCP2 antibodies or AhFibA among carriers and noncarriers for each of the four groups of HLA-DRB1 alleles encoding the SE, defined according to the new classification of HLA-DRB1 alleles (S1D, S2D, S3P, S3D). Odds and odds ratios (95\% confidence intervals) were also calculated. The dose effect was investigated for alleles positively or negatively associated with immunological markers using tests for the trend of the log odds.

Statistical analyses were performed using Stata Statistical Software (release 9.1 SE; Stata Corporation, College Station, TX, USA). All $P$ values were two-sided, and $P<0.05$ was considered statistically significant after correcting when relevant for multiple testing according to the Benjamini-Yekutieli 2001 method.

\section{Results \\ Demographic and immunologic characteristics of RA patients}

The main baseline demographic and immunologic characteristics of the 160 patients with early RA included in the present study were the following: 120 women (75\%) and 40 men $(25 \%)$; mean ( \pm standard deviation) age, 50.31 ( \pm 14.03) years; mean ( \pm standard deviation) disease duration, 0.55 ( \pm 0.02) years; number (\%) RF-positive, 110/160 (68.75\%); number (\%) anti-CCP2 antibody-positive, 110/160 (68.75\%); and number (\%) AhFibA-positive, 108/160 (67.25\%).

\section{Allele frequencies for HLA-DRB1 polymorphisms}

The frequencies of HLA-DRB1 alleles, classified into five groups according to the new classification, were as follows: S1, 59/320 (18.4\%); S2, 65/320 (20.3\%); S3D, 42/320 (13.3\%); S3P, 89/320 (27.81\%); and X, 65/320 (20.31). No departures from Hardy-Weinberg equilibrium were found for HLA-DRB1 alleles classified into the five groups $(P=0.7171$; 10 degrees of freedom).

\section{Relationship between HLA-DRB1 allele carrier status and RF status}

Table 2 presents the status for RF among patients carrying the different HLA-DRB1 alleles encoding the SE classified into four groups according to the new classification. On the one hand, S2 carriers had a higher frequency of RF in comparison with noncarriers (odds ratio $>1$ and $P<0.05$ ). On the other hand, S3D and S1 carriers had a lower frequency of RF in comparison with noncarriers (odds ratio $<1$ and $P<0.05$ ).

These results support the hypothesis of an association between HLA-DRB1 gene polymorphisms and RF, and the results point out the interest of the new classification of HLADRB1 alleles in order to differentiate predisposing and protective alleles for RF production in early RA.

\section{Relationship between HLA-DRB1 allele carrier status and anticitrullinated protein/peptide autoantibody status}

Table 3 presents the status for anti-CCP2 antibodies or AhFibA among patients carrying the different HLA-DRB1 alleles encoding the SE classified into four groups according to the new classification. On the one hand, S2 and S3P carriers had a higher frequency of anti-CCP2 antibodies or AhFibA in comparison with noncarriers (odds ratio $>1$ and $P<0.05$ ). On the other hand, S3D and S1 carriers had a lower frequency of anti-CCP2 antibodies or AhFibA in comparison with noncarriers (odds ratio $<1$ and $P<0.05$ ).

The interest of the new classification is that both predisposing and protective alleles for the production of ACPA are found. The effects remain significant after correction for multiple testing using the Benjamini-Yekutieli 2001 procedure implemented in STATA 9.0 (State Corporation), which corrects for an overall false discovery rate ( $5 \%$ here) (see Table 3$)$. In the present analysis based on carrier status, a potential bias may be introduced by the presence of an adverse effect allele in the control group. In the analysis of the $\mathrm{S} 2$ effect, for example, the association may be overestimated by the presence of S3D carriers in the control group (noncarrier of S2). The effect of S2 may similarly be underestimated by the presence of S3P carriers. After controlling for the adverse effect of S3D and S1 in the analysis of $S 2$, the association with the positivity of Ahfiba remains significant $(P<0.05)$. After controlling for the adverse effect of S2 and S3P in the analysis of S3D, the association with negativity of anti-CCP2 remained significant.

These results support the hypothesis of an association between HLA-DRB1 gene polymorphisms and ACPAs, and point out the interest of the new classification of HLA-DRB1 alleles in order to differentiate predisposing and protective alleles for ACPA production in early RA.

\section{Discussion}

The results of the present study confirm previous evidence of an association between HLA-DRB1 gene polymorphisms and RF or ACPAs in RA. Furthermore, the results point out the interest of the new classification of HLA-DRB1 alleles in order 
Table 1

HLA-DRB1 amino acid sequence for alleles observed among rheumatoid arthritis patients and their classification according to du Montcel and colleagues

\begin{tabular}{|c|c|c|c|c|c|c|c|c|c|}
\hline \multirow[t]{2}{*}{ HLA-DRB1 allele } & \multicolumn{8}{|c|}{ Amino acid position } & \multirow[t]{2}{*}{ Classification of du Montcel and colleagues } \\
\hline & 69 & 70 & 71 & 72 & 73 & 74 & 75 & 76 & \\
\hline HLA-DRB1*0101 & $\mathrm{E}$ & $\mathbf{a}$ & $\mathbf{R}$ & $\mathbf{R}$ & A & A & V & $\mathrm{D}$ & S3P \\
\hline HLA-DRB1*0102 & - & $\mathbf{a}$ & $\mathbf{R}$ & $\mathbf{R}$ & A & A & - & - & S3P \\
\hline HLA-DRB1*0103 & - & $\mathrm{D}$ & $\mathbf{E}$ & $\mathbf{R}$ & A & A & - & - & S1 \\
\hline HLA-DRB1*03 & - & - & $\mathrm{K}$ & - & G & $\mathrm{R}$ & - & - & $x$ \\
\hline HLA-DRB1*0401 & - & $\mathrm{Q}$ & $\mathrm{K}$ & $\mathbf{R}$ & A & A & - & - & S2 \\
\hline HLA-DRB1*0402 & - & $\mathrm{D}$ & $E$ & $\mathbf{R}$ & A & A & - & - & S1 \\
\hline HLA-DRB1*0403 & - & - & - & - & - & $E$ & - & - & $x$ \\
\hline HLA-DRB1*0404 & - & $\mathbf{a}$ & $\mathbf{R}$ & $\mathbf{R}$ & A & A & - & - & S3P \\
\hline HLA-DRB1*0405 & - & $\mathbf{a}$ & $\mathbf{R}$ & $\mathbf{R}$ & A & A & - & - & S3P \\
\hline HLA-DRB1*0407 & - & - & - & - & - & $E$ & - & - & $x$ \\
\hline HLA-DRB1*0408 & - & $\mathbf{a}$ & $\mathbf{R}$ & $\mathbf{R}$ & A & A & - & - & S3P \\
\hline HLA-DRB1*0411 & - & - & - & - & - & $E$ & - & - & $x$ \\
\hline HLA-DRB1*07 & - & $\mathrm{D}$ & - & - & $\mathrm{G}$ & Q & - & - & $x$ \\
\hline HLA-DRB1*08 & - & $\mathrm{D}$ & - & - & - & L & - & - & $x$ \\
\hline HLA-DRB1*0901 & - & $\mathrm{R}$ & - & - & - & $E$ & - & - & $x$ \\
\hline HLA-DRB1*1001 & - & $\mathbf{a}$ & $\mathbf{R}$ & $\mathbf{R}$ & A & A & - & - & S3P \\
\hline HLA-DRB1*1101 & - & D & $\mathbf{R}$ & $\mathbf{R}$ & A & A & - & - & S3D \\
\hline HLA-DRB1*1102 & - & $\mathrm{D}$ & $E$ & $\mathbf{R}$ & A & A & - & - & S1 \\
\hline HLA-DRB1*1103 & - & $\mathrm{D}$ & $E$ & $\mathbf{R}$ & A & A & - & - & S1 \\
\hline HLA-DRB1*1104 & - & D & $\mathbf{R}$ & $\mathbf{R}$ & A & A & - & - & S3D \\
\hline HLA-DRB1*12 & - & D & $\mathbf{R}$ & $\mathbf{R}$ & A & A & - & - & S3D \\
\hline HLA-DRB1*1301 & - & $\mathrm{D}$ & $E$ & $\mathbf{R}$ & A & A & - & - & S1 \\
\hline HLA-DRB1*1302 & - & $\mathrm{D}$ & $E$ & $\mathbf{R}$ & A & A & - & - & S1 \\
\hline HLA-DRB1*1303 & - & $\mathrm{D}$ & $\mathrm{K}$ & $\mathbf{R}$ & A & A & - & - & S2 \\
\hline HLA-DRB1*1323 & - & $\mathrm{D}$ & $E$ & $\mathbf{R}$ & A & A & - & - & S1 \\
\hline HLA-DRB1*1401 & - & $\mathrm{R}$ & - & - & - & $E$ & - & - & $x$ \\
\hline HLA-DRB1*1402 & - & $\mathbf{a}$ & $\mathbf{R}$ & $\mathbf{R}$ & A & A & - & - & S3P \\
\hline HLA-DRB1*1404 & - & $\mathrm{R}$ & - & - & - & $E$ & - & - & $x$ \\
\hline HLA-DRB1*15 & - & $\mathrm{Q}$ & A & $\mathbf{R}$ & A & A & - & - & S1 \\
\hline HLA-DRB $1 * 16$ & - & D & $\mathbf{R}$ & $\mathbf{R}$ & A & A & - & - & S3D \\
\hline
\end{tabular}

In the du Montcel and colleagues classification [35], the HLA-DRB1 alleles were first divided into two groups according to the presence or absence of the RAA sequence at positions 72-74, which denote $S$ and $X$ alleles (respectively shared epitope and nonshared epitope alleles). The $S$ alleles were subsequently divided into four groups according to the two first amino acids at positions 70 and 71 (boldface): S1 for ARAA and ERAA, S2 for KRAA, S3 for RRAA (divided into S3P for QRRAA and S3D for DRRAA according to position 70), and X for all non-RAA motifs. The conventional classification of the amino acids was used, here divided into three biochemical subgroups, as follows: group $1=G$ for glycine, $A$ for alanine, $\mathrm{V}$ for valine, $\mathrm{L}$ for leucine (aliphatic amino acids (nonpolar hydrophobic)); group $2=\mathrm{K}$ for lysine, $\mathrm{R}$ for arginine (basic amino acids (polar and positively charged)); group $3=\mathrm{E}$ for glutamic acid, $\mathrm{Q}$ for glutamine (the amide corresponding to $\mathrm{E}$ ), $\mathrm{D}$ for aspartic acid, and $\mathrm{N}$ for asparagine (the amide corresponding to D) (acidic amino acids and corresponding amides are very hydrophilic; acidic amino acids are polar and negatively charged at physiologic $\mathrm{pH}$, amides are polar and uncharged, and not ionizable) [36]. 
Relationship between HLA-DRB1 allele carrier status and rheumatoid factor status in French patients with early rheumatoid arthritis

\begin{tabular}{|c|c|c|c|c|c|}
\hline & \multicolumn{2}{|c|}{ Carrier status } & \multirow[t]{2}{*}{ Odds ratio ( $95 \%$ confidence interval) } & \multirow[t]{2}{*}{$P$} & \multirow[t]{2}{*}{$P$ for trend } \\
\hline & Yes & No & & & \\
\hline \multicolumn{6}{|l|}{ S1 carrier } \\
\hline Rheumatoid factor-positive & $31(55.4)$ & $79(75.9)$ & $0.39(0.19-0.83)$ & 0.0118 & $0.0051^{*}$ \\
\hline Rheumatoid factor-negative & $25(44.6)$ & $25(24.0)$ & & & \\
\hline \multicolumn{6}{|l|}{ S2 carrier } \\
\hline Rheumatoid factor-positive & $49(83.1)$ & $61(60.4)$ & $3.21(1.39-7.9)$ & $0.0028^{*}$ & $0.0049^{*}$ \\
\hline Rheumatoid factor-negative & $10(16.9)$ & $40(39.6)$ & & & \\
\hline \multicolumn{6}{|l|}{ S3P carrier } \\
\hline Rheumatoid factor-positive & $57(74.0)$ & $53(63.9)$ & $1.61(0.78-3.38)$ & 0.1766 & 0.4478 \\
\hline Rheumatoid factor-negative & $20(26.0)$ & $30(36.1)$ & & & \\
\hline \multicolumn{6}{|l|}{ S3D carrier } \\
\hline Rheumatoid factor-positive & $19(51.4)$ & $91(74.0)$ & $0.37(0.16-0.86)$ & 0.0145 & 0.0209 \\
\hline Rheumatoid factor-negative & $18(48.6)$ & $32(26.0)$ & & & \\
\hline
\end{tabular}

Data presented as $n$ (\%). Status for rheumatoid factor among 160 patients with early rheumatoid arthritis, carrying the different HLA-DRB1 alleles encoding the shared epitope classified into four groups according to the new classification. Odds ratios, $95 \%$ alpha-risk confidence interval and $P$ value for exact Fisher test. The dose effect was investigated for alleles positively or negatively associated with immunological markers using tests for trend of the log odds. *Significant after correcting for multiple testing according to the Benjamini-Yekutieli 2001 method at an overall critical $P$ value of $5 \%$.

to differentiate predisposing and protective alleles for autoantibody production in early RA.

The results of the present study confirm previous evidence of an association between HLA-DRB1 gene polymorphisms and autoantibody production in RA. We found a positive association between carriers of $\mathrm{HLA}-\mathrm{DRB} 1{ }^{*} \mathrm{SE}^{+}$alleles (HLADRB $1{ }^{\star} 0401$, HLA-DRB1*0404, HLA-DRB1*0405, HLADRB $1{ }^{*} 0408$, HLA-DRB $\left.1{ }^{\star} 1001\right)$ and RF or ACPA production, while we did not find any negative association between carriers of HLADRB1 ${ }^{*}$ SE- alleles and RF or ACPA production (data not shown). An association between HLA-DRB $1{ }^{\star} 04$ or HLA$\mathrm{DRB} 1{ }^{*} \mathrm{SE}^{+}$alleles and $\mathrm{RF}$ has been reported in some studies $[12,30,40]$ but rejected in others $[12,32,41]$. An association between HLA-DRB1*01, HLA-DRB1 ${ }^{*} 04$ or HLA-DRB1 ${ }^{\star} \mathrm{SE}^{+}$ alleles and ACPAs was more constantly reported in European or North American RA patients [9,12,24,30,32,40,42-45]. Since the presence of RF was strongly correlated with that of ACPAs in most of these studies, several groups investigated whether these associations between HLA-DRB1 gene polymorphisms and RF or ACPAs were independent. These studies showed that the association between $\mathrm{HLA}-\mathrm{DRB} 1{ }^{*} \mathrm{SE}^{+}$ alleles and ACPAs is constantly stronger than the association between HLA-DRB1 ${ }^{\star} \mathrm{SE}^{+}$alleles and RF. Furthermore, they suggested that the association between HLA-DRB1*SE+ alleles and ACPAs is independent of the RF status, leading to the conclusion that $\mathrm{HLA}-\mathrm{DRB} 1{ }^{*} \mathrm{SE}^{+}$alleles are primarily associated with the presence of ACPAs, but not with the presence of RF $[24,32,41]$.
The results of the present study indicate the interest of the new classification of HLA-DRB1 alleles to differentiate predisposing and protective alleles for autoantibody production in early RA. This new classification, which is based on an initial split of HLA-DRB1 alleles into two groups according to the presence ( $S$ alleles) or absence ( $X$ alleles) of the RAA sequence at positions 72-74, subsequently divides $S$ alleles into four groups according to the amino acids at positions 71 and 70 . Most of the previous studies, based on the common classification, identified HLA-DRB1*101, HLA-DRB1*0401, HLA-DRB1*404 and HLA-DRB1*1001 as predisposing alleles for ACPA production in RA, with a significant dose effect in patients carrying two of these predisposing alleles $[9,12,32,44]$. Only a few association studies reported an HLADRB1 allelic protective effect for ACPA production in RA. In these studies, HLA-DRB1*03 was associated with ACPAnegative RA and decreased titers of ACPAs, even in the presence of an SE allele [32,45]. In the new classification of HLADB1 allelles, HLA-DRB1*03 is not taken into account separately since it is classified into the $X$ group of alleles, which do not encode the SE sequence. In the present study, complementary analysis did not show any association between HLADRB1 ${ }^{*} 03$ carrier status and RF or ACPA production (data not shown). The use of the classification by du Montcel and colleagues suggests a risk hierarchy in ACPA production in early RA patients: the S2 (KRAA at positions 71-74) and S3P (QRRAA or RRRAA at positions 70-74) alleles conferring predisposition, while the S1 (ARAA or ERAA at positions 7174) and S3D (DRRAA at positions 70-74) alleles confer pro- 
Table 3

Relationship between HLA-DRB1 allele carrier status and anticitrullinated protein/peptide autoantibody status in French patients with early rheumatoid arthritis

\begin{tabular}{|c|c|c|c|c|c|}
\hline & \multicolumn{2}{|c|}{ Carrier status } & \multirow[t]{2}{*}{ Odds ratio (95\% confidence interval) } & \multirow[t]{2}{*}{$P$} & \multirow[t]{2}{*}{$P$ for trend } \\
\hline & Yes & No & & & \\
\hline \multicolumn{6}{|l|}{ S1 carrier } \\
\hline CCP2-positive & $32(57.1)$ & $78(75.0)$ & $0.44(0.21-0.94)$ & 0.0312 & 0.0134 \\
\hline CCP2-negative & $24(42.9)$ & $26(25.0)$ & & & \\
\hline AhFibA-positive & $31(55.4)$ & $77(74.0)$ & $0.43(0.21-0.91)$ & 0.0213 & 0.0113 \\
\hline AhFibA-negative & $25(44.6)$ & $27(26.0)$ & & & \\
\hline \multicolumn{6}{|l|}{ CCP2-positive } \\
\hline CCP2-negative & $49(83.1)$ & $61(60.4)$ & $3.21(1.39-7.9)$ & $0.0028^{*}$ & $0.0049^{*}$ \\
\hline AhFibA-positive & $10(16.9)$ & $40(39.6)$ & & & \\
\hline AhFibA-negative & $50(84.8)$ & $58(57.4)$ & $4.12(1.75-10.49)$ & $0.0004^{\star}$ & $0.0003^{\star}$ \\
\hline CCP2-positive & $9(15.2)$ & $43(42.6)$ & & & \\
\hline \multicolumn{6}{|l|}{ S3P carrier } \\
\hline CCP2-positive & $61(79.2)$ & $49(59.0)$ & $2.65(1.24-5.74)$ & $0.0066^{\star}$ & $0.0014^{\star}$ \\
\hline CCP2-negative & $16(20.8)$ & $34(41.0)$ & & & \\
\hline AhFibA-positive & $61(79.2)$ & $47(56.6)$ & $2.92(1.38-6.32)$ & $0.0025^{\star}$ & $0.0035^{\star}$ \\
\hline AhFibA-negative & $16(20.8)$ & $36(43.4)$ & & & \\
\hline \multicolumn{6}{|l|}{ S3D carrier } \\
\hline CCP2-positive & $17(45.9)$ & $93(75.6)$ & $0.27(0.12-0.63)$ & $0.0011^{*}$ & $0.0009^{*}$ \\
\hline CCP2-negative & $20(54.1)$ & $30(24.4)$ & & & \\
\hline AhFibA-positive & $19(51.4)$ & $89(72.4)$ & $0.4(0.18-0.93)$ & 0.0266 & 0.0145 \\
\hline AhFibA-negative & $18(48.6)$ & $34(27.6)$ & & & \\
\hline
\end{tabular}

Data presented as $n$ (\%). Status for anticyclic citrullinated peptides (anti-CCP2) antibodies or antideiminated human fibrinogen autoantibodies (AhFibA) among 160 patients with early rheumatoid arthritis, carrying the different HLA-DRB1 alleles encoding the shared epitope classified into four groups according to the new classification. Odds ratios, 95\% alpha-risk confidence interval and $P$ value for exact Fisher test. The dose effect was investigated for alleles positively or negatively associated with immunological markers using tests for trend of the log odds. ${ }^{\star}$ Significant after correcting for multiple testing according to the Benjamini-Yekutieli 2001 method at an overall critical $P$ value of $5 \%$.

tection, in comparison with $\mathrm{X}$ (non-RAA patterns at positions 72-74).

The use of the new classification of HLA-DRB1 alleles proposed by du Montcel and colleagues seems to provide different pictures of the relative contribution of the HLA-DRB1 locus to RA pathogenesis. This relative contribution is not restricted to ACPA production, but also includes risk hierarchy for RA susceptibility and structural severity [35-37].

Trying to understand the findings of genetic association/linkage studies in complex multifactorial diseases, such as RA, in light of the amino acid alignment of a protein encoded by a candidate gene remains a challenging task. In fact, the interac- tions between HLA-DRB1 molecules and citrullinated peptides may impact RA pathogenesis in several ways. For example, a previous study conducted in DR4-IE transgenic mice demonstrated that the conversion of arginine to citrulline at the peptide side-chain position interacting with the SE significantly increases peptide-MHC affinity and leads to the activation of CD4+ $T$ cells, suggesting that HLA-DRB1 alleles encoding the SE could initiate an autoimmune response to citrullinated self-antigens [46].

\section{Conclusion}

Although no formal conclusions on causality can be drawn from the present association study, our findings indicate the interest of this new classification of HLA-DRB1 alleles in order 
to differentiate predisposing and protective alleles for autoantibody production in RA.

\section{Competing interests}

The authors declare that they have no competing interests.

\section{Authors' contributions}

P-AG and ACo took the leadership of the study in both clinical immunological and statistical aspects. FC and PD contributed specifically to the genotyping. GS and LN were specifically in charge of the autoantibody study. AC-T contributed to the statistical analysis. BM, $\mathrm{ACa}$ and J-FB contributed through the assessment of the RMP cohort.

\section{Acknowledgements}

The authors acknowledge the contribution of Delphine Nigon as a clinical research data manager as well as the help of the Computational platform for Clinical research and Analysis in Epidemiology \& Public Health Midi-Pyrenees (TIERSMIP).

\section{References}

1. El-Gabalawy HS, Duray $P$, Goldbach-Mansky R: Evaluating patients with arthritis of recent onset: studies in pathogenesis and prognosis. JAMA 2000, 284:2368-2373.

2. Scott DL: The diagnosis and prognosis of early arthritis: rationale for new prognostic criteria. Arthritis Rheum 2002, 46:286-290.

3. Girbal-Neuhauser E, Durieux JJ, Arnaud M, Dalbon P, Sebbag M, Vincent C, Simon M, Senshu T, Masson-Bessiere C, Jolivet-Reynaud $\mathrm{C}$, et al:: The epitopes targeted by the rheumatoid arthritis-associated antifilaggrin autoantibodies are posttranslationally generated on various sites of (pro)filaggrin by deimination of arginine residues. J Immunol 1999, 162:585-594.

4. Schellekens GA, de Jong BA, van den Hoogen FH, van de Putte LB, van Venrooij WJ: Citrulline is an essential constituent of antigenic determinants recognized by rheumatoid arthritisspecific autoantibodies. J Clin Invest 1998, 101:273-281.

5. Nienhuis RL, Mandema E: A new serum factor in patients with rheumatoid arthritis; the antiperinuclear factor. Ann Rheum Dis 1964, 23:302-305.

6. Young A, Jaraquemada D, Awad J, Festenstein H, Corbett M, Hay FC, Roitt IM: Association of HLA-DR4/Dw4 and DR2/Dw2 with radiologic changes in a prospective study of patients with rheumatoid arthritis. Preferential relationship with HLA-Dw rather than HLA-DR specificities. Arthritis Rheum 1984, 27:20-25.

7. Simon M, Girbal E, Sebbag M, Gomes-Daudrix V, Vincent C, Salama G, Serre G: The cytokeratin filament-aggregating protein filaggrin is the target of the so-called "antikeratin antibodies,' autoantibodies specific for rheumatoid arthritis. J Clin Invest 1993, 92:1387-1393.

8. Schellekens GA, Visser $H$, de Jong $B A$, van den Hoogen $F H$, Hazes JM, Breedveld FC, van Venrooij WJ: The diagnostic properties of rheumatoid arthritis antibodies recognizing a cyclic citrullinated peptide. Arthritis Rheum 2000, 43:155-163.

9. Auger I, Sebbag M, Vincent C, Balandraud N, Guis S, Nogueira L, Svensson B, Cantagrel A, Serre G, Roudier J: Influence of HLADR genes on the production of rheumatoid arthritis-specific autoantibodies to citrullinated fibrinogen. Arthritis Rheum 2005, 52:3424-3432.

10. Chapuy-Regaud S, Nogueira L, Clavel C, Sebbag M, Vincent C, Serre G: IgG subclass distribution of the rheumatoid arthritisspecific autoantibodies to citrullinated fibrin. Clin Exp Immunol 2005, 139:542-550.

11. Masson-Bessiere C, Sebbag M, Girbal-Neuhauser E, Nogueira L, Vincent C, Senshu T, Serre G: The major synovial targets of the rheumatoid arthritis-specific antifilaggrin autoantibodies are deiminated forms of the alpha- and beta-chains of fibrin. $J$ Immunol 2001, 166:4177-4184

12. Berglin $E$, Padyukov $L$, Sundin $U$, Hallmans $G$, Stenlund $H$, Van Venrooij WJ, Klareskog L, Dahlqvist SR: A combination of autoantibodies to cyclic citrullinated peptide (CCP) and HLADRB1 locus antigens is strongly associated with future onset of rheumatoid arthritis. Arthritis Res Ther 2004, 6:R303-R308.

13. Nielen MM, van Schaardenburg D, Reesink HW, van de Stadt RJ, van der Horst-Bruinsma IE, de Koning MH, Habibuw MR, Vandenbroucke JP, Dijkmans BA: Specific autoantibodies precede the symptoms of rheumatoid arthritis: a study of serial measurements in blood donors. Arthritis Rheum 2004, 50:380-386.

14. van Gaalen FA, Linn-Rasker SP, van Venrooij WJ, de Jong BA Breedveld FC, Verweij CL, Toes RE, Huizinga TW: Autoantibodies to cyclic citrullinated peptides predict progression to rheumatoid arthritis in patients with undifferentiated arthritis: a prospective cohort study. Arthritis Rheum 2004, 50:709-715.

15. Visser $\mathrm{H}$, le Cessie S, Vos K, Breedveld FC, Hazes JM: How to diagnose rheumatoid arthritis early: a prediction model for persistent (erosive) arthritis. Arthritis Rheum 2002, 46:357-365

16. von Essen $R$, Kurki $\mathrm{P}$, Isomaki $\mathrm{H}$, Okubo $\mathrm{S}$, Kautiainen $\mathrm{H}$, Aho K: Prospect for an additional laboratory criterion for rheumatoid arthritis. Scand J Rheumatol 1993, 22:267-272.

17. Jansen $A L$, van der Horst-Bruinsma I, van Schaardenburg $D$, van de Stadt RJ, de Koning MH, Dijkmans BA: Rheumatoid factor and antibodies to cyclic citrullinated peptide differentiate rheumatoid arthritis from undifferentiated polyarthritis in patients with early arthritis. J Rheumatol 2002, 29:2074-2076.

18. Kroot EJ, de Jong $B A$, van Leeuwen MA, Swinkels $H$, van den Hoogen FH, van't Hof M, van de Putte LB, van Rijswijk MH, van Venrooij WJ, van Riel PL: The prognostic value of anti-cyclic citrullinated peptide antibody in patients with recent-onset rheumatoid arthritis. Arthritis Rheum 2000, 43:1831-1835.

19. Vincent C, Nogueira L, Sebbag M, Chapuy-Regaud S, Arnaud M, Letourneur O, Rolland D, Fournie B, Cantagrel A, Jolivet M, et al:: Detection of antibodies to deiminated recombinant rat filaggrin by enzyme-linked immunosorbent assay: a highly effective test for the diagnosis of rheumatoid arthritis. Arthritis Rheum 2002, 46:2051-2058.

20. Meyer O, Labarre C, Dougados M, Goupille P, Cantagrel A, Dubois A, Nicaise-Roland P, Sibilia J, Combe B: Anticitrullinated protein/peptide antibody assays in early rheumatoid arthritis for predicting five year radiographic damage. Ann Rheum Dis 2003, 62:120-126.

21. Paimela L, Gripenberg M, Kurki P, Leirisalo-Repo M: Antikeratin antibodies: diagnostic and prognostic markers for early rheumatoid arthritis. Ann Rheum Dis 1992, 51:743-746.

22. van Jaarsveld $\mathrm{CH}$, ter Borg EJ, Jacobs JW, Schellekens GA Gmelig-Meyling FH, van Booma-Frankfort C, de Jong BA, van Venrooij WJ, Bijlsma JW: The prognostic value of the antiperinuclear factor, anti-citrullinated peptide antibodies and rheumatoid factor in early rheumatoid arthritis. Clin Exp Rheumatol 1999, 17:689-697.

23. Vencovsky J, Machacek S, Sedova L, Kafkova J, Gatterova J, Pesakova V, Ruzickova S: Autoantibodies can be prognostic markers of an erosive disease in early rheumatoid arthritis. Ann Rheum Dis 2003, 62:427-430.

24. van der Helm-van Mil AH, Verpoort KN, Breedveld FC, Huizinga TW, Toes RE, de Vries RR: The HLA-DRB1 shared epitope alleles are primarily a risk factor for anti-cyclic citrullinated peptide antibodies and are not an independent risk factor for development of rheumatoid arthritis. Arthritis Rheum 2006, 54:1117-1121.

25. Newton JL, Harney SM, Wordsworth BP, Brown MA: A review of the MHC genetics of rheumatoid arthritis. Genes Immun 2004, 5:151-157.

26. Seldin MF, Amos Cl, Ward R, Gregersen PK: The genetics revolution and the assault on rheumatoid arthritis. Arthritis Rheum 1999, 42:1071-1079.

27. Stastny P: Mixed lymphocyte cultures in rheumatoid arthritis. $J$ Clin Invest 1976, 57:1148-1157.

28. Gregersen PK, Silver J, Winchester RJ: The shared epitope hypothesis. An approach to understanding the molecular genetics of susceptibility to rheumatoid arthritis. Arthritis Rheum 1987, 30:1205-1213. 
29. Gorman JD, Lum RF, Chen JJ, Suarez-Almazor ME, Thomson G, Criswell LA: Impact of shared epitope genotype and ethnicity on erosive disease: a meta-analysis of 3,240 rheumatoid arthritis patients. Arthritis Rheum 2004, 50:400-412.

30. van Gaalen FA, van Aken J, Huizinga TW, Schreuder GM, Breedveld FC, Zanelli E, van Venrooij WJ, Verweij CL, Toes RE, de Vries RR: Association between HLA class II genes and autoantibodies to cyclic citrullinated peptides (CCPs) influences the severity of rheumatoid arthritis. Arthritis Rheum 2004, 50:2113-2121.

31. Hoppe B, Haupl T, Gruber R, Kiesewetter H, Burmester GR, Salama A, Dorner T: Detailed analysis of the variability of peptidylarginine deiminase type 4 in German patients with rheumatoid arthritis: a case-control study. Arthritis Res Ther 2006, 8:R34.

32. Irigoyen $\mathrm{P}$, Lee AT, Wener MH, Li W, Kern M, Batliwalla F, Lum RF, Massarotti E, Weisman M, Bombardier C, et al:: Regulation of anti-cyclic citrullinated peptide antibodies in rheumatoid arthritis: contrasting effects of HLA-DR3 and the shared epitope alleles. Arthritis Rheum 2005, 52:3813-3818.

33. de Vries $\mathrm{N}$, Tijssen $\mathrm{H}$, van Riel PL, van de Putte LB: Reshaping the shared epitope hypothesis: HLA-associated risk for rheumatoid arthritis is encoded by amino acid substitutions at positions 67-74 of the HLA-DRB1 molecule. Arthritis Rheum 2002, 46:921-928.

34. Reviron D, Perdriger A, Toussirot E, Wendling D, Balandraud N, Guis S, Semana G, Tiberghien P, Mercier P, Roudier J: Influence of shared epitope-negative HLA-DRB1 alleles on genetic susceptibility to rheumatoid arthritis. Arthritis Rheum 2001, 44:535-540.

35. du Montcel ST, Michou L, Petit-Teixeira E, Osorio J, Lemaire I, Lasbleiz S, Pierlot C, Quillet P, Bardin T, Prum B et al: New classification of HLA-DRB1 alleles supports the shared epitope hypothesis of rheumatoid arthritis susceptibility. Arthritis Rheum 2005, 52:1063-1068.

36. Gourraud PA, Boyer JF, Barnetche T, Abbal M, Cambon-Thomsen A, Cantagrel A, Constantin A: A new classification of HLA-DRB1 alleles differentiates predisposing and protective alleles for rheumatoid arthritis structural severity. Arthritis Rheum 2006, 54:593-599.

37. Michou L, Croiseau P, Petit-Teixeira E, du Montcel ST, Lemaire I, Pierlot C, Osorio J, Frigui W, Lasbleiz S, Quillet P, et al.: Validation of the reshaped shared epitope HLA-DRB1 classification in rheumatoid arthritis. Arthritis Res Ther 2006, 8:R79.

38. Arnett FC, Edworthy SM, Bloch DA, McShane DJ, Fries JF, Cooper NS, Healey LA, Kaplan SR, Liang MH, Luthra HS, et al.: The American Rheumatism Association 1987 revised criteria for the classification of rheumatoid arthritis. Arthritis Rheum 1988, 31:315-324

39. Zanelli E, Breedveld FC, de Vries RR: HLA class II association with rheumatoid arthritis: facts and interpretations. Hum Immunol 2000, 61:1254-1261.

40. Forslind K, Ahlmen M, Eberhardt K, Hafstrom I, Svensson B: Prediction of radiological outcome in early rheumatoid arthritis in clinical practice: role of antibodies to citrullinated peptides (anti-CCP). Ann Rheum Dis 2004, 63:1090-1095.

41. Huizinga TW, Amos $\mathrm{Cl}$, van der Helm-van Mil AH, Chen W, van Gaalen FA, Jawaheer D, Schreuder GM, Wener M, Breedveld FC, Ahmad N, et al.: Refining the complex rheumatoid arthritis phenotype based on specificity of the HLA-DRB1 shared epitope for antibodies to citrullinated proteins. Arthritis Rheum 2005, 52:3433-3438.

42. Bas S, Perneger TV, Mikhnevitch E, Seitz M, Tiercy JM, Roux-Lombard P, Guerne PA: Association of rheumatoid factors and antifilaggrin antibodies with severity of erosions in rheumatoid arthritis. Rheumatology (Oxford) 2000, 39:1082-1088.

43. Boki KA, Kurki P, Holthofer H, Tzioufas AG, Drosos AA, Moutsopoulos HM: Prevalence of antikeratin antibodies in Greek patients with rheumatoid arthritis. A clinical, serologic, and immunogenetic study. J Rheumatol 1995, 22:2046-2048.

44. Goldbach-Mansky R, Lee J, McCoy A, Hoxworth J, Yarboro C, Smolen JS, Steiner G, Rosen A, Zhang C, Menard HA, et al:: Rheumatoid arthritis associated autoantibodies in patients with synovitis of recent onset. Arthritis Res 2000, 2:236-243.

45. Verpoort KN, van Gaalen FA, van der Helm-van Mil AH, Schreuder GM, Breedveld FC Huizinga TW, de Vries RR, Toes RE. Association of HLA-DR3 with anti-cyclic citrullinated peptide anti- body-negative rheumatoid arthritis. Arthritis Rheum 2005, 52:3058-3062

46. Hill JA, Southwood S, Sette A, Jevnikar AM, Bell DA, Cairns E: Cutting edge: the conversion of arginine to citrulline allows for a high-affinity peptide interaction with the rheumatoid arthritis-associated HLA-DRB1*0401 MHC class II molecule. J Immunol 2003, 171:538-541. 